\title{
PERANAN KOMODITI PERTANIAN UNGGULAN TIAP KECAMATAN DALAM PEREKONOMIAN WILAYAH KABUPATEN BANTUL
}

\author{
Fauzi Afnan, Darsono, Wiwit Rahayu \\ Program Studi Agribisnis Fakultas Pertanian, Universitas Sebelas Maret Surakarta \\ E-mail: afnanfauzi2@yahoo.com
}

\begin{abstract}
The aims of this research were to identify the pre-eminent agriculture commodity, to know specialization and localization of pre-eminent agriculture commodity, and to know the role of pre-eminent commodity in regional economics based on income surplus and income multiplier. The basic method that be used in this research is descriptive analytic. The data analysis used Location Quotient, Specialization Quotient, Localization Quotient, Income Surplus and Income Multiplier. The results showed that the pre-eminent agricultural commodities in many subdistricts in Bantul district are field paddy, sugar cane, teak, beef cattle, and catfish. Paddy field and beef cattle are commodities that is specialized in Bantul district. While from 148 pre-eminent commodities, 114 commodities are concentrated in certain subdistrict and 34 commodities spread in several subdistricts. Income surplus of pre-eminent agricultural commodities in Bantul district is equal to $R p$ 200,035,908,784 and the average income surplus in every subdistrict is equal to $R p$ 11,766,818,164. Multiplier income is equal to $R p 1,407$ that means when income of pre-eminent agricultural commodities increase equal to $R p 1.00$ will contribute to the total income of agricultural commodities amount to $R p 1.4077$.
\end{abstract}

Keywords: pre-eminent agricultural commodity, specialization and localization, income surplus, income multiflier

\begin{abstract}
Abstrak: Penelitian ini bertujuan mengidentifikasi komoditi pertanian unggulan, mengetahui spesialisasi dan lokalisasi komoditi pertanian unggulan, dan mengetahui peranan komoditi pertanian unggulan terhadap perekonomian wilayah dilihat dari surplus pendapatan serta pengganda pendapatan. Metode dasar yang digunakan adalah deskriptif analitis. Metode analisis data yang digunakan analisis Location Quotient, Kuosien Spesialisasi, Kuosien Lokalisasi, Surplus Pendapatan dan Pengganda Pendapatan. Hasil penelitian menunjukkan bahwa komoditi pertanian yang menjadi unggulan di banyak kecamatan di Kabupaten Bantul adalah padi sawah, tebu, jati, sapi potong, dan lele. Komoditi padi sawah dan sapi potong merupakan komoditi yang terspesialisasi di Kabupaten Bantul. Dari 148 komoditi unggulan, 114 komoditi memusat di kecamatan tertentu dan 34 komoditi pertanian menyebar di beberapa kecamatan. Rata-rata surplus pendapatan komoditi pertanian unggulan di Kabupaten Bantul tahun 2010-2014 sebesar Rp 200.035.908.784 dan rata-rata suplus pendapatan komoditi pertanian unggulan tiap kecamatan sebesar Rp 11.766.818.164. Pengganda pendapatan komoditi pertanian sebesar 1,4077 artinya setiap kenaikan $\mathrm{Rp} 1,00$ pendapatan dari komoditi pertanian unggulan yang dihasilkan akan memberikan kontribusi terhadap pendapatan total komoditi pertanian sebesar Rp 1,4077.
\end{abstract}

Kata Kunci: komoditas pertanian unggulan, spesialisasi dan lokalisasi, surplus pendapatan, pengganda pendapatan 


\section{PENDAHULUAN}

Pembangunan merupakan proses yang mencakup peningkatan pertumbuhan ekonomi dan penanganan ketimpangan pendapatan dengan tujuan untuk mewujudkan masyarakat yang makmur. Perencanaan pembangunan ekonomi adalah upaya pemerintah yang dilakukan secara sengaja dan hati-hati untuk mengkoordinasikan keputusan ekonomi. Keputusan ekonomi ditujukan untuk mempengaruhi, mengarahkan, dan mengendalikan tingkat pertumbuhan ekonomi dengan tujuan akhir terpenuhinya tujuan pembangunan. (Kuncoro, 2014). Sistem perencanaan pembangunan ekonomi akan menjamin adanya keseimbangan antara prioritas nasional dengan aspirasi lokal dalam perencanaan pembangunan daerah (Tarigan, 2002).

Sebagai upaya dalam menunjang keberhasilan pembangunan, pemerintah Indonesia telah melaksanakan otonomi daerah yang merupakan wujud kepercayaan terhadap kemampuan daerah dalam menyelenggarakan dan mengelola pembangunan. Pembangunan di daerah perlu dilakukan sebagai upaya meningkatkan peran serta masyarakat daerah di dalam mengelola sumberdaya yang ada sehingga daerah diharapkan mampu berperan lebih maksimal dalam pembangunan ekonomi (Irawan dan Suparmoko, 2002).

Kabupaten Bantul merupakan bagian dari wilayah Daerah Istimewa Yogyakarta yang melaksanakan otonomi daerah. Pembangunan wilayah Kabupaten Bantul didukung oleh berbagai sektor ekonomi. Sektor pertanian memiliki peran penting dalam pembangunan Kabupaten Bantul karena memberikan kontribusi terbesar terhadap Produk Domestik Regional Bruto. Selama tahun 2010-2014, secara berturut-turut sektor pertanian memberikan kontribusi terhadap PDRB sebesar $24,32 \%, 23,52 \%, 22,04 \%, 21,72 \%$, dan $19,84 \%$ (Bappeda Kabupaten Bantul, 2015).

Keberadaan potensi sektor pertanian yang dimiliki Kabupaten Bantul tidak terlepas dari kontribusi potensi sektor pertanian di tingkat wilayah yang lingkupnya lebih kecil yakni wilayah kecamatan. Perencanaan pembangunan yang utuh menjadikan pembangunan di tingkat kabupaten dapat dilaksanakan secara komprehensif hingga pada tingkat kecamatan. Setiap kecamatan di Kabupaten Bantul mempunyai kesempatan untuk mengembangkan sektor pertanian melalui pemanfaatan potensi yang tersedia.

Salah satu pengoptimalan sumber daya guna menunjang pembangunan wilayah kecamatan dapat dilakukan dengan mengidentifikasi komoditi pertanian unggulan masing-masing kecamatan sebagai upaya dalam penentuan strategi pembangunan pertanian di Kabupaten Bantul. Penentuan komoditi pertanian unggulan dan peranannya dalam pembangunan wilayah akan memudahkan pemerintah daerah dalam perencanaan dan pengambilan kebijakan pembangunan pertanian melalui pengembangan pertanian di tiap kecamatan di Kabupaten Bantul.

Berdasarkan latar belakang tersebut, penelitian ini bertujuan untuk mengidentifikasi komoditi pertanian unggulan, mengetahui spesialisasi dan lokalisasi komoditi pertanian unggulan, dan mengetahui peranan komoditi pertanian unggulan terhadap perekonomian wilayah Kabupaten Bantul dilihat dari surplus pendapatan serta pengganda pendapatan.

\section{METODE PENELITIAN}

Metode dasar yang digunakan dalam penelitian ini adalah deskriptif analitis (Surakhmad, 2004). Lokasi Penelitian adalah Kabupaten Bantul yang dipilih secara sengaja (purposive) (Sarwono, 2004). Data yang digunakan adalah data sekunder berupa data Rencana Pembangunan Jangka Menengah Daerah (RPJMD) Kabupaten Bantul tahun 2010-2014, data produksi komoditi pertanian Kabupaten Bantul tahun 2010-2014, data produksi komoditi pertanian tiap kecamatan di Kabupaten Bantul tahun 2010-2014, data indeks harga produsen rata-rata komoditi pertanian Kabupaten Bantul tahun 2010-2014, dan Kabupaten Bantul dalam angka tahun 2010-2014.

\section{Metode Analisis Data}

1. Analisis Penetuan Komoditas Pertanian Unggulan Tiap Kecamatan Di Kabupaten Bantul 
Penentuan komoditas unggulan tiap kecamatan dilakukan dengan analisis LQ yang dihitung dengan rumus:

$$
L Q=\frac{k_{i} / k_{t}}{K_{i} / K_{t}}
$$

Dimana : LQ : Indeks Location Quotient komoditi pertanian di kecamatan i Kabupaten Bantul, $\mathbf{k}_{\mathbf{i}}$ : Nilai produksi komoditi pertanian i pada tingkat kecamatan di Kabupaten Bantul, $\mathbf{k}_{\mathbf{t}} \quad$ : Nilai produksi total komoditi pertanian pada tingkat kecamatan di Kabupaten Bantul, $\mathbf{K}_{\mathbf{i}}$ : Nilai produksi komoditi pertanian i pada tingkat Kabupaten Bantul, dan $\mathbf{K}_{\mathbf{t}}$ : Nilai produksi total komoditi pertanian pada tingkat Kabupaten Bantul

Berdasarkan nilai LQ, komoditas pertanian diklasifikasikan menjadi:

a. LQ>1, artinya komoditi pertanian termasuk komoditi unggulan.

b. $\mathrm{LQ}=1$, artinya komoditi pertanian termasuk komoditi bukan unggulan.

c. LQ<1, artinya komoditi pertanian termasuk komoditi bukan unggulan. (Kuncoro, 2014).

2. Analisis Spesialisasi dan Lokalisasi Komoditi Pertanian Unggulan di Kabupaten Bantul

a. Kuosien Spesialisasi

Untuk mengetahui apakah di suatu wilayah terdapat spesialisasi terhadap komoditi pertanian tertentu atau tidak dilakukan dengan melihat besarnya nilai Kuosien Spesialisasi (KS) yang diperoleh dengan menggunakan rumus berikut

$$
\begin{gathered}
K S_{i}=\left(\frac{w_{i}}{w_{t}}\right)-\left(\frac{W_{i}}{W_{t}}\right) \\
K S=\sum_{p-1}^{n} K \operatorname{Sip}
\end{gathered}
$$

Dimana : $\mathbf{K S}_{\mathbf{i}}$ : Kuosien Spesialisasi terhadap komoditi I, $\mathbf{w}_{\mathbf{i}}$ : Nilai produksi komoditi pertanian i pada tingkat kecamatan di Kabupaten Bantul, $\mathbf{w}_{\mathbf{t}}$ : Nilai produksi total komoditi pertanian pada tingkat kecamatan di Kabupaten Bantul, $\mathbf{W}_{\mathbf{i}}$ : produksi komoditi pertanian i pada tingkat Kabupaten Bantul,
$\mathbf{W}_{\mathrm{t}}$ :Nilai produksi total komoditi pertanian pada tingkat Kabupaten Bantul, KS :Kuosien Spesialisasi, dan $\mathrm{KS}_{\mathrm{i}}: \mathrm{KSi}$ positif

Klasifikasi dilakukan dengan indikator jika nilai $\mathrm{KS} \sim 0$ berarti tidak ada spesialisasi komoditi i pada wilayah tersebut. Namun, apabila nilai $\mathrm{KS} \sim 1$ atau $\mathrm{KS} \geq 1$ berarti wilayah tersebut terspesialisasi terhadap komoditi I (Kuncoro, 2014).

\section{b. Kuosien Lokalisasi}

Tingkat penyebaran komoditi tertentu di suatu wilayah diketahui dengan melihat besarnya Kuosien Lokalisasi (Lo) yang dihitung dengan menggunakan rumus berikut :

$$
\begin{gathered}
L o_{i}=\left(\frac{W_{i}}{W_{i}}\right)-\left(\frac{w_{t}}{W_{t}}\right) \\
L o=\sum_{p-1}^{n} \text { Loip }
\end{gathered}
$$

Dimana: $\mathbf{L o}_{\mathbf{i}}$ : Koefisien Lokalisasi komoditi pertanian $\mathbf{I}, \mathbf{w}_{\mathbf{i}}$ : Nilai produksi komoditi pertanian i pada tingkat kecamatan di Kabupaten Bantul, $\mathbf{w}_{\mathbf{t}}$ : Nilai produksi total komoditi pertanian pada tingkat kecamatan di Kabupaten Bantul, $\mathbf{W}_{\mathbf{i}}$ : Nilai produksi komoditi pertanian i pada tingkat Kabupaten Bantul, $\mathbf{W}_{\mathbf{t}}$ : Nilai produksi total komoditi pertanian pada tingkat Kabupaten Bantul, Lo :Kuosien Lokalisasi, dan $\mathbf{L o}_{\mathbf{i}} \mathbf{p}$ : Lo i positif

Apabila nilai Lo $\sim 0$ berarti komoditi pertanian tersebut menyebar di beberapa wilayah. Namun, jika nilai Lo $\sim 1$ atau Lo $\geq 1$ maka komoditi pertanian memusat di suatu wilayah (Kuncoro, 2014).

3. Peranan Komoditi Pertanian Unggulan di Kabupaten Bantul

Peranan komoditi pertanian terhadap perekonomian wilayah Kabupaten Bantul diketahui dengan melihat surplus pendapatan dan pengganda pendapatanBesarnya surplus pendapatan tersebut diperoleh dari hasil perhitungan dengan menggunakan rumus berikut :

$$
S P=\sum\left[\left(\frac{S i}{S}\right)-\left(\frac{N i}{N}\right)\right] * S i
$$


Dimana : SP : Surplus pendapatan kecamatan, $\mathbf{S i}$ : Nilai produksi komoditi pertanian i pada tingkat kecamatan di Kabupaten Bantul, $\mathbf{S}$ : Nilai produksi total komoditi pertanian pada tingkat kecamatan di Kabupaten Bantul, Ni : Nilai produksi komoditi pertanian i pada tingkat Kabupaten Bantul, dan $\mathbf{N}$ :Nilai produksi total komoditi pertanian pada tingkat Kabupaten Bantul

Apabila besarnya surplus pendapatan bernilai positif berarti komoditi pertanian tersebut selain dapat memenuhi kebutuhan wilayah yang bersangkutan juga dapat memenuhi kebutuhan wilayah lain. Jika besarnya surplus pendapatan negatif berarti komoditi pertanian tersebut masih kurang dalam memenuhi kebutuhan wilayah yang bersangkutan (Tarigan, 2002).

Besarnya pengganda pendapatan dihitung dengan menggunakan rumus berikut :

$$
M=\sum \frac{\Delta Y}{\Delta Y B}
$$

Dimana : M : Pengganda pendapatan kecamatan, $\Delta \mathbf{Y}$ : Nilai produksi total komoditi pertanian, dan $\Delta \mathbf{Y B}$ : Nilai produksi total komoditi pertanian unggulan (Tarigan, 2002).

\section{HASIL DAN PEMBAHASAN}

Komoditi Pertanian Unggulan Masingmasing Kecamatan di Kabupaten Bantul

Komoditi pertanian unggulan adalah komoditi pertanian yang memiliki nilai Location Quotient lebih dari satu yang berarti komoditi pertanian tersebut mampu memenuhi kebutuhan wilayah dan mampu mengekspor ke wilayah lain. Hasil analisis LQ menunjukkan bahwa terdapat 148 komoditi pertanian di Kabupaten Bantul. Setiap kecamatan di Kabupaten Bantul memiliki potensi yang berbeda-beda sehingga jumlah komoditi pertanian unggulan tiap kecamatan juga berbeda.

Tabel 1. Komoditi Pertanian Unggulan di Banyak Kecamatan Menurut Subsektor Pertanian di Kabupaten Bantul Tahun 2010-2014

\begin{tabular}{|c|c|c|c|c|}
\hline Subsektor & $\begin{array}{l}\text { Komoditi } \\
\text { Pertanian }\end{array}$ & Tahun & $\begin{array}{c}\text { Jumlah } \\
\text { Kecamatan }\end{array}$ & Nilai Location Quetient Tertinggi \\
\hline Tanaman & Padi sawah & 2010 & 10 & 1,667 (Kecamatan Pandak) \\
\hline Bahan & & 2011 & 9 & 1,540 (Kecamatan Bantul) \\
\hline \multirow[t]{3}{*}{ Makanan } & & 2012 & 8 & 1,654 (Kecamatan Jetis) \\
\hline & & 2013 & 9 & 1,625 (Kecamatan Jetis) \\
\hline & & 2014 & 8 & 1,726 (Kecamatan Jetis) \\
\hline \multirow[t]{5}{*}{ Perkebunan } & Tebu & 2010 & 8 & 2,510 (Kecamatan Bambanglipuro) \\
\hline & & 2011 & 9 & 2,436 (Kecamatan Pajangan) \\
\hline & & 2012 & 9 & 2,477 (Kecamatan Bambanglipuro) \\
\hline & & 2013 & 9 & 2,773 (Kecamatan Bambanglipuro) \\
\hline & & 2014 & 10 & 2,757 (Kecamatan Bambanglipuro) \\
\hline \multirow{5}{*}{ Kehutanan } & Jati & 2010 & 9 & 2,407 (Kecamatan Srandakan) \\
\hline & & 2011 & 8 & 2,151 (Kecamatan Pundong) \\
\hline & & 2012 & 8 & 2,893 (Kecamatan Pundong) \\
\hline & & 2013 & 8 & 2,890 (Kecamatan Pundong) \\
\hline & & 2014 & 8 & 2,804 (Kecamatan Pundong) \\
\hline \multirow{5}{*}{ Peternakan } & Sapi potong & 2010 & 9 & 1,952 (Kecamatan Pajangan \\
\hline & & 2011 & 10 & 1,656 (Kecamatan Pajangan) \\
\hline & & 2012 & 10 & 1,586 (Kecamatan Pajangan) \\
\hline & & 2013 & 11 & 1,755 (Kecamatan Pajangan) \\
\hline & & 2014 & 9 & 1,901 (Kecamatan Pajangan) \\
\hline \multirow[t]{5}{*}{ Perikanan } & Lele & 2010 & 6 & 2,925 (Kecamatan Piyungan) \\
\hline & & 2011 & 5 & 2,162 (Kecamatan Sewon) \\
\hline & & 2012 & 5 & 2,354 (Kecamatan Sewon) \\
\hline & & 2013 & 8 & 2,342 (Kecamatan Piyungan) \\
\hline & & 2014 & 6 & 4,509 (Kecamatan Piyungan) \\
\hline
\end{tabular}

Sumber : Analisis Data Sekunder, 2016 
Dari hasil analisis LQ tiap kecamatan diketahui bahwa Kecamatan Srandakan memiliki komoditi unggulan terbanyak yaitu 61 jenis komoditi dan Kecamatan Bantul memiliki komoditi unggulan paling sedikit yaitu 16 komoditi.

Dilihat dari komoiti unggulan yang banyak diuasahakan di kecamatan-kecamatan di Kabupaten Bantul, diketahui bahwa padi sawah, tebu, jati, sapi potong, dan lele merupakan komoditi unggulan yang banyak diusahakan di kecamatan-kecamatan di kabupaten Bantul. Hal ini disajikan di Tabel 1.

Tabel 1. menunjukkan bahwa untuk subsektor tanaman bahan makanan, komoditi padi sawah menjadi unggulan di 8 kecamatan dengan nilai LQ tertinggi sebesar 1,726 dimiliki Kecamatan Jetis. Subsektor perkebunan, komoditi tebu menjadi unggulan di 10 kecamatan dengan nilai LQ tertinggi sebesar 2,757 dimiliki Kecamatan Bambanglipuro. Subsektor kehutanan, komoditi jati menjadi unggulan di 8 kecamatan dengan nilai LQ tertinggi sebesar 2,804 dimiliki Kecamatan Pundong. Subsektor peternakan, komoditi sapi potong menjadi unggulan pada 9 kecamatan dengan nilai LQ tertinggi sebesar 1,901 dimiliki Kecamatan Pajangan. Subsektor perikanan, yakni komoditi lele yang menjadi unggulan pada 6 kecamatan dengan nilai LQ tertinggi sebesar 4,509 dimiliki Kecamatan Piyungan.

Dalam rangka mengembangkan sector pertanian, Kabupaten Bantul melakukan langkah-langkah dan upaya pengembangan. Beberapa desain langkah taktis yang dilakukan Pemerintah Daerah Kabupaten Bantul adalah mendukung petani untuk mempertahankan areal sawahnya, peningkatan peran penyuluh pertanian, peningkatan diversifikasi usaha tani, dan peningkatan kemitraan dengan pihak lain terutama yang menguntungkan petani (Wastutiningsih dan Untari, 2011).

\section{Spesialisasi dan Lokalisasi Komoditi Pertanian Unggulan di Kabupaten Bantul}

Analisis spesialisasi dan lokalisasi dilakukan untuk mengetahui wilayah basis dari komoditi pertanian unggulan. Besarnya nilai kuosien spesialisasi (KS) digunakan untuk mengetahui apakah di suatu wilayah terdapat spesialisasi terhadap komoditi pertanian tertentu atau tidak. Sedangkan kuosien lokalisasi digunakan untuk melihat tingkat penyebaran (aglomerasi) komoditi tertentu di suatu wilayah (Bachrein, 2000).

Hasil analisis spesialisasi komoditi pertanian unggulan di Kabupaten Bantul menunjukkan bahwa di Kabupaten Bantul terdapat dua komoditi pertanian unggulan yang memiliki nilai koefisien kuosien spesialisasi (KS) mendekati satu yaitu padi sawah dan sapi potong dengan nilai $\mathrm{KS}$ rata-rata sebesar 0,711 dan 0,655. Hal ini berarti bahwa padi sawah dan sapi potong merupakan komoditi yang terspesialisasi di Kabupaten Bantul. Komoditi padi sawah dan sapi potong memiliki keunggulan komparatif yang relatif lebih tinggi jika dibandingkan komoditi lain di Kabupaten Bantul. Bachrein (2000) menyatakan bahwa keunggulan komparatif berhubungan dengan keefektifan suatu wilayah dalam melakukan suatu kegiatan pertanian dalam hal ini adalah opportunity cost suatu daerah dalam memilih mengusahakan komoditi tertentu yang lebih rendah.

Hasil analisis lokalisasi komoditas pertanian unggulan di Kabupaten Bantul menunjukkan bahwa dari 148 komoditi pertanian unggulan di Kabupaten Bantul, terdapat 114 komoditi memusat di suatu kecamatan tertentu dan 34 komoditi pertanian yang menyebar di beberapa kecamatan di Kabupaten Bantul. Komoditi Diffenbachia merupakan komoditi pertanian yang memiliki nilai Lo tertinggi sebesar 0,966. Hal ini disebabkan keberadaan komoditi Diffenbachia memusat di satu kecamatan yaitu di Kecamatan Kasihan. Dinas Pertanian dan Kehutanan Kabupaten Bantul (2015) mengemukakan bahwa, diffenbachia merupakan tanaman hias populer yang biasa ditanam di pekarangan. Keindahannya berasal dari bentuk tajuk dan juga warna daunnya yang bervariasi yakni hijau dengan bercak-bercak hijau muda atau kuning. Diffenbachia di kalangan penjual tanaman hias di Kabupaten Bantul dikenal pula sebagai daun bahagia atau bunga bahagia.

\section{Peranan Komoditi Pertanian Unggulan di Kabupaten Bantul}

Peranan komoditi pertanian unggulan terhadap perekonomian wilayah Kabupaten Bantul dilihat dari surplus pendapatan dan pengganda pendapatan. 
Fauzi Afnan, Darsono dan Wiwit R. : Peranan Komoditi Pertanian Unggulan ...

Tabel 2. Total Surplus Pendapatan Nilai Produksi Komoditi Pertanian Unggulan Tiap Kecamatan di Kabupaten Bantul Tahun 2010-2014

\begin{tabular}{lrr}
\hline \multicolumn{1}{c}{ Kecamatan } & Surplus Pendapatan (Rp) & Prosentase (\%) \\
\hline Kretek & 25.280 .991 .543 & 12,63 \\
Sanden & 20.168 .858 .098 & 10,08 \\
Jetis & 15.796 .002 .420 & 7,89 \\
Dlingo & 13.375 .420 .738 & 6,68 \\
Pajangan & 12.520 .533 .970 & 6,25 \\
Pandak & 12.001 .139 .486 & 5,99 \\
Sedayu & 11.711 .304 .605 & 5,85 \\
Banguntapan & 11.681 .791 .031 & 5,83 \\
Sewon & 11.489 .617 .121 & 5,74 \\
Bantul & 11.245 .429 .937 & 5,62 \\
Srandakan & 10.624 .722 .960 & 5,31 \\
Imogiri & 10.227 .632 .035 & 5,11 \\
Bambanglipuro & 9.801 .573 .681 & 4,89 \\
Pleret & 8.183 .687 .625 & 4,09 \\
Piyungan & 7.175 .450 .001 & 3,58 \\
Pundong & 4.877 .638 .648 & 2,43 \\
Kasihan & 3.874 .114 .885 & 1,93 \\
\hline Kabupaten Bantul & 200.035 .908 .784 & 100,00 \\
\hline Rata-rata & 11.766 .818 .164 & \\
\hline Sumber : Analisis Data Sekunder, 2016 & & \\
\hline
\end{tabular}

Surplus pendapatan komoditi pertanian unggulan tiap kecamatan di Kabupaten Bantul

Setiap komoditi pertanian unggulan akan menghasilkan surplus pendapatan. Hal ini karena komoditi pertanian unggulan mampu memenuhi kebutuhan wilayah kecamatan tersebut dan mampu mengekspor ke luar wilayah kecamatan. Komoditi pertanian unggulan yang diekspor ke wilayah lain akan menghasilkan pendapatan sehingga mampu memberikan kontribusi terhadap pendapatan wilayah yang bersangkutan. Surplus pendapatan setiap kecamatan di Kabupaten Bantul tahun 2010-2014 dapat dilihat pada Tabel 2.

Tabel 2. menunjukkan bahwa secara umum surplus pendapatan komoditi pertanian unggulan di Kabupaten Bantul tahun 20102014 sebesar Rp 200.035.908.784 dengan suplus pendapatan rata-rata komoditi pertanian unggulan tiap kecamatan sebesar $\mathrm{Rp}$ 11.766.818.164. Nilai surplus pendapatan di Kabupaten Bantul yang positif, menunjukkan bahwa sektor pertanian mempunyai peranan atau kontribusi dalam perekonomian Kabupaten Bantul. Hal ini disebabkan karena adanya ekspor komoditi pertanian unggulan yang pada akhirnya akan meningkatkan pendapatan di sektor pertanian. Semakin besar nilai surplus pendapatan yang dimiliki oleh suatu kecamatan di Kabupaten Bantul maka hal ini menggambarkan semakin besar pula ekspor komoditi unggulan yang ada di wilayah tersebut ke luar daerah.

Kecamatan Kretek memiliki nilai surplus pendapatan komoditi pertanian unggulan terbesar yaitu sebesar Rp 25.280.991.543, artinya Kecamatan Kretek memberikan kontribusi terbesar dalam pembentukan surplus pendapatan total komoditi pertanian unggulan di Kabupaten Bantul yaitu sebesar 12,63\%. Kecamatan Kretek memiliki 43 komoditi pertanian unggulan. Sedangkan Kecamatan Kasihan dengan 36 komoditi pertanian unggulan, memiliki nilai surplus pendapatan komoditi pertanian unggulan terkecil yaitu sebesar Rp 3.874.114.885.

\section{Pengganda pendapatan komoditi pertanian unggulan tiap kecamatan di Kabupaten Bantul}

Rahmat (2011) mengemukakan bahwa pada dasarnya pertumbuhan ekonomi dalam suatu wilayah terjadi karena adanya efek pengganda dari pembelanjaan kembali pendapatan yang diperoleh melalui penjualan barang dan jasa yang dihasilkan wilayah itu yang dipasarkan ke luar wilayah. Besarnya efek kekuatan pengganda tersebut mendorong pertumbuhan 
Fauzi Afnan, Darsono dan Wiwit R. : Peranan Komoditi Pertanian Unggulan ...

Tabel 3. Total Pengganda Pendapatan Nilai Produksi Komoditi Pertanian Unggulan Tiap Kecamatan di Kabupaten Bantul Tahun 2010-2014

\begin{tabular}{lccr}
\hline \multicolumn{1}{c}{ Kecamatan } & $\begin{array}{c}\text { Nilai Produksi } \\
\text { Total Komoditi } \\
\text { Pertanian (Rp) }\end{array}$ & $\begin{array}{c}\text { Nilai Produksi Total } \\
\text { Komoditi Pertanian } \\
\text { Unggulan (Rp) }\end{array}$ & $\begin{array}{c}\text { Pengganda } \\
\text { Pendapatan }\end{array}$ \\
\hline Kretek & 238.427 .492 .185 & 121.079 .353 .025 & 1,9691 \\
Sanden & 257.969 .265 .680 & 136.382 .791 .930 & 1,8915 \\
Imogiri & 230.247 .955 .934 & 143.642 .174 .671 & 1,6029 \\
Piyungan & 262.429 .058 .089 & 166.412 .268 .237 & 1,5769 \\
Srandakan & 158.244 .028 .662 & 109.762 .158 .271 & 1,4416 \\
Bantul & 172.612 .692 .915 & 119.771 .814 .645 & 1,4411 \\
Sedayu & 162.996 .153 .571 & 115.073 .808 .771 & 1,4164 \\
Jetis & 192.748 .920 .219 & 136.341 .784 .717 & 1,4137 \\
Sewon & 203.723 .444 .446 & 144.125 .747 .613 & 1,3956 \\
Pleret & 167.155 .596 .542 & 119.767 .606 .614 & 1,2788 \\
Banguntapan & 220.882 .943 .752 & 172.719 .941 .536 & 1,2503 \\
Pajangan & 134.308 .959 .457 & 107.414 .397 .725 & 1,2498 \\
Dlingo & 284.851 .339 .916 & 227.905 .906 .642 & 1,2259 \\
Bambanglipuro & 233.691 .526 .956 & 190.626 .322 .187 & 1,1642 \\
Pundong & 159.035 .351 .270 & 136.598 .134 .522 & 1,1008 \\
Kasihan & 126.482 .886 .329 & 114.895 .400 .859 & 1,0987 \\
Pandak & 175.991 .940 .204 & 160.169 .507 .902 & $\mathbf{1 , 4 0 7 7}$ \\
\hline Kabupaten Bantul & $\mathbf{3 . 3 8 1 . 7 9 9 . 5 5 6 . 1 2 9}$ & $\mathbf{2 . 4 2 2 . 6 8 9 . 1 1 9 . 8 6 7}$ & \\
\hline Sumber: Analisis
\end{tabular}

Sumber : Analisis Data Sekunder, 2016

ekonomi yang ditunjukkan oleh koefisien pengganda yang dihasilkan. Pengganda pendapatan setiap kecamatan di wilayah Kabupaten Bantul tahun 2010-2014 disajikan pada Tabel 3.

Tabel 3. menunjukkan bahwa secara umum pengganda pendapatan komoditi pertanian unggulan di Kabupaten Bantul sebesar 1,4077 artinya setiap kenaikan Rp 1,00 pendapatan dari komoditi pertanian unggulan akan meningkatkan pendapatan total komoditi pertanian sebesar Rp 1,4077. Besarnya angka pengganda pendapatan komoditi pertanian unggulan menunjukkan seberapa besar peranan komoditi pertanian unggulan terhadap perekonomian di Kabupaten Bantul. Semakin besar koefisien pengganda yang dihasilkan, maka semakin besar pula kekuatan efek pengganda tersebut untuk mendorong pertumbuhan ekonomi suatu wilayah dan sebaliknya.

Nilai koefisien pengganda pendapatan komoditi pertanian unggulan tertinggi di Kabupaten Bantul terdapat di Kecamatan Kretek yaitu sebesar 1,9691, artinya setiap kenaikan Rp 1,00 pendapatan dari komoditi pertanian unggulan di Kecamatan Kretek akan memberikan kontribusi terhadap pendapatan total komoditi pertanian di Kecamatan Kretek sebesar Rp 1,9691. Pengganda pendapatan terendah di Kecamatan Pandak sebesar 1,0987.

\section{KESIMPULAN}

1. Komoditi pertanian yang menjadi unggulan di banyak kecamatan di Kabupaten Bantul adalah padi sawah, tebu, jati, sapi potong, dan lele.

2. Komoditi padi sawah dan sapi potong merupakan komoditi yang terspesialisasi di Kabupaten Bantul. Dari 148 komoditi pertanian unggulan, sebanyak 114 komoditi memusat di kecamatan tertentu dan 34 komoditi pertanian menyebar di beberapa kecamatan.

3. Rata-rata surplus pendapatan komoditi pertanian unggulan di Kabupaten Bantul tahun 2010-2014 sebesar Rp 200.035.908.784 dan rata-rata suplus pendapatan komoditi pertanian unggulan tiap kecamatan sebesar Rp 11.766.818.164. Kecamatan yang memiliki surplus pendapatan tertinggi adalah Kecamatan Kretek yaitu sebesar Rp 25.280.991.543 dan kecamatan dengan surplus pendapatan terendah adalah Kecamatan Kasihan yaitu sebesar Rp 3.874.114.885. 
4. Pengganda pendapatan komoditi pertanian sebesar 1,4077 artinya setiap kenaikan $\mathrm{Rp}$ 1,00 pendapatan dari komoditi pertanian unggulan yang dihasilkan akan memberikan kontribusi terhadap pendapatan total komoditi pertanian sebesar Rp 1,4077. Pengganda pendapatan tertinggi wilayah kecamatan di Kabupaten Bantul adalah Kecamatan Kretek yaitu sebesar 1,9691. Pengganda pendapatan terendah di Kecamatan Pandak sebesar 1,0987 .

\section{DAFTAR PUSTAKA}

Bachrein, S. 2000. Penetapan Komoditas Unggulan Propinsi. Balai Pengkajian dan Pengembangan Teknologi Pertanian. Bogor. http://www. bp2tp.litbang.deptan.go.id. Diakses tanggal 9 April 2015.

Badan Pusat Statistik Kabupaten Bantul. 2015. Kabupaten Bantul dalam Angka 2015. Badan Pusat Statistik Kabupaten Bantul. Bantul.

BAPPEDA Kabupaten Bantul. 2015. RPJMD Kabupaten Bantul 2011-2015. Badan Perencanaan dan Pembangunan Daerah Kabupaten Bantul. Bantul.

Kuncoro, M., 2014. Otonomi Daerah: Menuju Era Baru Pembangunan Daerah (3rd ed.). Penerbit Erlangga. Yogyakarta.
Irawan dan M. Suparmoko. 2002. Ekonomika Pembangunan Edisi Ke-6. BPFE. Yogyakarta.

Rahmat, M., 2011. Peran Sektor Kehutanan Dalam Perekonomian Kabupaten Ogan Komering Ulu Selatan. Jurnal Penelitian Sosial dan Ekonomi Kehutanan Vol. 8(2), pp. 110-121. Balai Penelitian Kehutanan Palembang. Palembang.

Sarwono, J., 2004. Metode Penelitian Kuantitatif dan Kualitatif. Penerbit Graha Ilmu. Jakarta.

Surakhmad, W., 2004. Pengantar Penelitian Ilmiah : Metode Dasar dan Metode Teknik. Penerbit Transito. Bandung.

Tarigan, R., 2002. Perencanaan Pembangunan Wilayah: Pendekaatan Ekonomi dan Ruang. Direktorat Jenderal Pendidikan Tinggi Departemen Pendidikan Nasional. Jakarta.

Wastutiningsih, S.P dan Untari, D.W., 2011. Kebijakan Pengembangan Pangan Lokal di Kabupaten Bantul. Prosiding Seminar Nasional Hasil Penelitian Jurusan Sosial Ekonomi Pertanian di Yogyakarta. Universitas Gadjah Mada, Yogyakarta. 